ENTREPRENEURSHIP AND SUSTAINABILITY ISSUES

ISSN 2345-0282 (online) http://jssidoi.org/jesi/

2020 Volume 7 Number 3 (March)

http://doi.org/10.9770/jesi.2020.7.3(27)

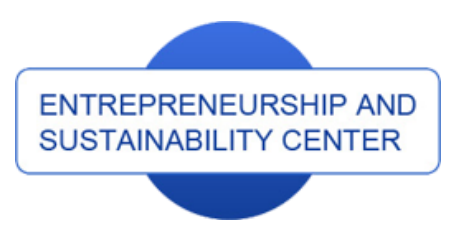

Publisher

http://jssidoi.org/esc/home
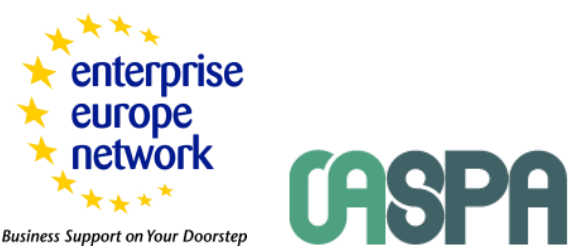

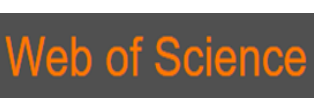

1 Clarivate

Analytics

\title{
CHALLENGES OF ENTERPRISE RESOURCE PLANNING (ERP) IMPLEMENTATION IN AGRICULTURE ${ }^{*}$
}

\author{
Ivan Kulikov ${ }^{1}$, Aleksandr Semin ${ }^{2}$, Egor Skvortsov ${ }^{3}$, Natalia Ziablitckaia ${ }^{4}$, Ekaterina Skvortsova ${ }^{5}$ \\ ${ }^{1}$ All-Russian Horticultural Institute for Breeding, Agrotechnology and Nursery (ARHIBAN) Moskov, Zagoryevskaya \\ str. d. 4, 115598, Russian Federation \\ ${ }^{2}$ Ural State Economic University, Ekaterinburg, March 8 str./Narodnaya Volya st., 62/45620144 Russian Federation \\ ${ }^{3}$ Ural Federal University, Ekaterinburg Mira str., 19, 620002, Russian Federation \\ ${ }^{4}$ South Ural State University, Chelyabinsk, pr.Lenina, 76, 454080, Russian Federation \\ ${ }^{5}$ Ural state agrarian university, Ekaterinburg, Karl Liebknecht str., 42, 620075, Russian Federation
}

E-mails: ${ }^{1}$ vstisp@vstisp.org, ${ }^{2}$ aleks_ural_55@mail.ru, ${ }^{3}$ easkvortcov@mail.ru, ${ }^{4}$ econ10@ rambler.ru,${ }^{5}$ uralmash91@list.ru

Received 10 September 2019; accepted 15 November 2019; published 30 March 2020

\begin{abstract}
The underlying assumption of the study is that ERP systems can crucially facilitate information exchange; yet, the agricultural sector is slow in their adoption due to different reasons, including a shortage of skilled personnel as well as a lack of knowledge about ERP capabilities among top managers and key employees. The study intends to identify challenges and prospects for ERP implementation in agriculture. The applied methods include the analysis of WoS publications and questionnaire surveys of executives of 55 companies operating in the Middle Urals' agricultural sector. ERP systems can be defined as comprehensive software solutions aimed to integrate business and management processes through a holistic approach and a single information system. According to expert estimates, in today's Russia the projects related to the agro-industrial sector account for $1-2 \%$ to $10-15 \%$ of the projects from the leading ERP vendors, including 1C, Bars Group, and Navigator-Agro. ERP systems in agriculture help improve business performance, reduce and monitor costs. These systems are effective in decision-making and can serve as the basis for precision agriculture. The main barriers are poor personnel skills and competencies, shortage of funds for ERP adoption, poorly developed or absent infrastructure, difficulties of fitting and adapting of ERP systems to agricultural business. In addition, agricultural business owners show no confidence in high-tech solutions and poor knowledge of the above systems. Other problems include operation complexity and insufficient government support in ERP implementation. The results of the study can be used by government authorities in their programs for innovative development and technical upgrading of the agriculture industry.
\end{abstract}

Keywords: ERP systems; agriculture; digital agriculture; resource monitoring; business activity planning

Reference to this paper should be made as follows: Kulikov I., Semin A., Skvortsov E., Ziablitckaia N., Skvortsova E. 2020. Challenges of enterprise resource planning (ERP) implementation in agriculture. Entrepreneurship and Sustainability Issues, 7(3), 1847-1857. https://doi.org/10.9770/jesi.2020.7.3(27)

JEL Classifications: O33, Q16, O32

Additional disciplines: digital economy, digital agriculture

*The reported study was funded by RFBR and Sverdlovsk region, project number 19-41-000001, Russian Federation 


\section{ENTREPRENEURSHIP AND SUSTAINABILITY ISSUES}

ISSN 2345-0282 (online) http://jssidoi.org/jesi/

2020 Volume 7 Number 3 (March)

http://doi.org/10.9770/jesi.2020.7.3(27)

\section{Introduction}

In recent years, Russia has become increasingly interested in development of digital technologies. The adopted Strategy of Scientific and Technological Development of the Russian Federation till 2030 outlined priority objectives, including the transition to digital, intelligent production technologies and robotic systems in the next 10-15 years. The program is aimed to create adequate conditions and infrastructure, to train employees to achieve leadership in selected fields of scientific and technological development, to build an integrated national innovative system. The strategy will be implemented through the action plan, including mechanism and anticipated results, and the scientific-technical program for agricultural development till 2025. Adoption of digital technologies is hardly possible without respective tools, including enterprise resource planning (ERP) systems.

Adoption of enterprise application software by agricultural businesses is attracting increasing attention from business people and scholars; this interest has resulted in a growing number of scientific publications and is easy to understand: Enterprise software and enterprise resource planning systems, in particular, provide an essential tool for monitoring company resources and transactions with a single system (Davenport and Brooks, 2004).

ERP systems are standardized software packages and are based on industry best practices. In addition, ERP systems meet the demand for integrated solutions, replace outdated systems, help eliminate incompatible information systems and data redundancy, reduce maintenance costs and create a single platform for the business (Ross and Vitale, 2000).

Manufacturing resource planning (MRP II) systems that evolved from material requirement planning (MRP) systems developed in the 1970s were forerunners to ERP systems. MRP II tracks additional aspects of production, not addressed in the previous systems.

ERP systems, in their current form, came into use in the 1990s. The main difference between ERP systems and their predecessors is that ERP is designed to run the entire company and support all core business processes, while the earlier systems were focused on specific functions such as production planning and production-related operations (Haddara and Elragal, 2013). Since the 1990s companies have been adopting ERP systems to improve efficiency and to provide smooth and seamless flow of information across departments and functional units (Akkermans and Van Helden, 2002). Lately, on-premise ERP systems have been replaced by cloud-based or hybrid systems. Cloud computing is seen as the key strategic technology with massive growth potential (Peng and Gala, 2014), capable of changing the traditional way of using information technology in companies. Traditional ERP implementations are increasingly giving way to cloud-based ERP systems, which are steadily gaining popularity (Bento et al. 2015).

It should be noted that implementation of ERP in agriculture has not been sufficiently studied both in Russia and other countries. Agricultural businesses find it difficult to adopt ERP systems due to lack of scientific research, insufficient feasibility study of ERP implementation and benefits, lack of adoption guidelines, and lack of consistent training of employees on using ERP software in agriculture. This provides the rationale for study.

\section{Problem setting and analysis of approaches to the solution}

The primary assumption is that ERP systems can significantly improve the operational efficiency of an agricultural company; however, their low adoption rates are caused by a number of problems, including a shortage of skilled personnel as well as a lack of knowledge about ERP capabilities among top managers and key 


\section{ENTREPRENEURSHIP AND SUSTAINABILITY ISSUES}

ISSN 2345-0282 (online) http://jssidoi.org/jesi/

2020 Volume 7 Number 3 (March)

http://doi.org/10.9770/jesi.2020.7.3(27)

employees of agricultural companies.

The study was conducted in several steps. The first step included analysis of publications addressing the evolution of ERP systems. The review of literature was performed by using a systematic approach. We analyzed the Web of Science reference database by contents of articles published within the last 5 years. When screening literature, we analyzed texts to check if the articles had any relation to our study. As a result, we selected the most relevant and significant publications in peer-reviewed journals. The remaining articles did not have any relation to the problem under study, as they addressed ERP systems and agriculture indirectly, thus being rejected and not subject to further reading and analysis.

The second step involved questionnaire survey of top managers and key employees of agricultural companies operating in the Sverdlovsk Region. The questionnaire contained closed-ended questions. At the end of the questionnaire, respondents were offered to give examples of using ERP systems in agriculture. The survey allowed us to identify the awareness level of agricultural top managers regarding ERP systems as well as to assess their expectations and possible challenges in implementation of ERP systems. The survey was conducted among top managers and key employees of 55 agricultural companies in the Middle Urals. The average age of respondents was $48 ; 87.3 \%$ were male and $12.7 \%$ were female. Most of the respondents $(76.4 \%)$ are employees having university education; out of them, $12.7 \%$ have a bachelor's degree, $9.1 \%$ have a master's degree, and one respondent has a candidate of sciences degree.

For the final step we used SWOT analysis tools to assess the status and prospects for ERP implementation in the agricultural industry. We were able to identify strengths and weaknesses, to evaluate opportunities and threats associated with ERP implementation in agriculture.

The study is aimed to identify challenges and prospects of using ERP systems in agriculture. The academic novelty includes the identification of the most preferred areas of application of ERP-systems according to farmers (by the example of the Middle Urals), as well as the expected benefits and an estimated increase in the profitability level of production and the main barriers at applying of these technologies in agriculture. Research restrictions concern participation in the survey of farmers directly engaged in agricultural production without involving large holding structures which deal with product processing.

The results of the study can be used by government authorities in their programs for innovative development and technical upgrading of the agriculture industry.

\section{Application of ERP systems in agriculture}

The factors that can facilitate ERP adoption by agricultural companies are as follows: Farmers need to have a clear picture of raw material prices and exchange rate fluctuations, to manage production costs, and to deal with challenges of climatic changes to comply with the present-day requirements.

Implementation of ERP systems is a complex organizational and technical process. Technically, these systems are difficult to implement in terms of configuration, adaptation and conversion of the data from outdated systems. 


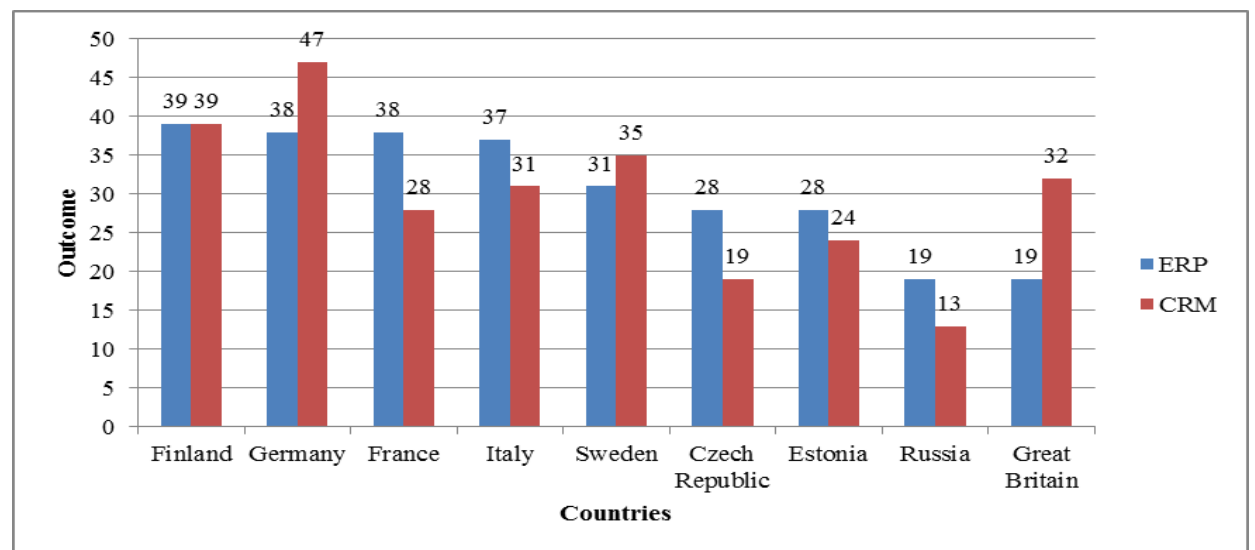

Fig. 1. ERP and CRM implementation by country: $2017^{*}$ (as a percentage of the total number of businesses) *Source: (Abdrakhmanova et al. 2002)

The above figure 1 shows that in 2017 Finland, France and Germany accounted for the highest percentage of the companies using ERP systems, Russia lagging far behind in implementation of ERP systems.

The process of ERP implementation brings about changes in business processes, work procedures, employees' roles and responsibilities. Besides, as ERP systems are elaborate and sophisticated, agricultural employees may find it difficult to understand and study them; therefore, they may need comprehensive training and refresher programs (Robey et al. 2002). Integrating all functions into one system, agricultural businesses intend to improve the efficiency by providing employees of different departments with an access to the same information through the shareable database. ERP systems are of fundamental significance for operation and supply chain management through seamless integration of processes, real-time access and data access, helping maintain competitive ability on global and local markets.

ERP systems can be defined as comprehensive software solutions aimed to integrate business and management processes through a holistic approach and a single information system (Costa et al. 2016; Klaus et al. 2000). ERP can be seen as an integrated system for automation of the flow of materials, information and financial resources by their integration in business processes (Vlasov et al. 2019, Acar et al. 2017).

According to expert estimates, projects related to the agriculture industry account for $1-2 \%$ to $10-15 \%$ of the projects from the leading software and hardware systems vendors. For example, out of 105 systems in the registry of 1C-Parus, only 4 systems are used in agriculture. In the registry of the BARS Group the ratio of total number of projects and projects serving the needs of the agriculture industry is 84 to 9, etc. In total, the registry includes more than 450 agriculture-related projects implemented by over 300 companies. In addition to traditional (not only for agriculture) accounting and ERP systems (1C (1C: Enterprise. 2019), BARS Group (BARS Agriculture. 2019), etc.) as well as security and monitoring systems (Navigator-Agro (Navigator - Agro. 2019), there are pilot GIS projects intended to meet needs of the agro-industrial sector (Centerprogramsystem (Industry Solutions. 2019) and Rostelecom (Rostelecom. 2019). To be fair, in their agriculture-related software solutions, leading Russian vendors and integrators did not go far from traditional and widely used inventory control systems.

Examples of ERP systems include databases related to weather changes, pest infestation and crop diseases as well as other production outcomes combined with data on prices for agricultural products. All the above can provide useful information for management decision making, which requires a database, data warehouse and data mining (Wolfert et al. 2017). ERP systems play an important role in development of precision agriculture. The data obtained through the above technology can be integrated into a harmonized system of agriculture management, including using the Internet of Things (Rao et al. 2012; Kaloxylos et al. 2012; Li et al. 2011) 
To a great extent, the efficiency of ERP systems depends on the field of application as well as on top managers' and employees' confidence in these systems (Mayeh et al. 2016). In the meantime, there is quite conflicting information about ERP benefits and their impact (Nwankpa, 2015). A number of scholars argue that less than 49\% of the ERP implementations are successful worldwide due to ERP complex nature (Mahmud et al. 2017). By studying determinants of ERP diffusion we can identify factors contributing to improved performance of agricultural companies that adopt ERP systems. The preliminary findings show that implementation of these systems can help agricultural companies/farmers improve their financial performance.

The ERP implementation process can be generally broken into the following steps:

- mapping out automation strategy;

- business performance analysis;

- organization restructuring;

- selection of a system;

- adoption of the system;

- operation.

Top managers' and key employees' assessment of prospects for ERP implementation in agriculture is of great importance. Expectations and awareness levels were identified through the survey conducted among top managers and key employees of agricultural companies.

Measuring of the amount of data received by top managers and key employees of agricultural companies from sensors, transmitters and other digital devices incorporated in ERP systems is of great importance (Fig. 2).

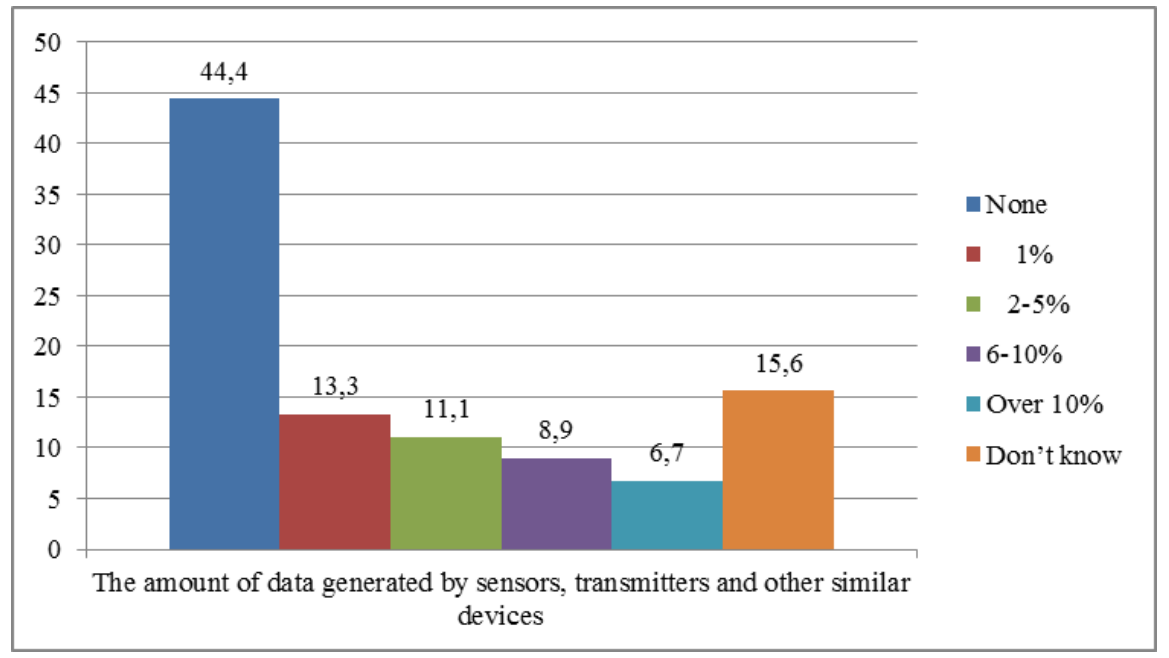

Fig. 2. Data received from sensors, transmitters and similar devices Source: authors, the respondents' opinion

The survey shows that $44.4 \%$ of top managers and key employees of agricultural companies do not use sensors and transmitters to obtain data. $15.6 \%$ of the respondents were at a loss to answer the question. Only $6.7 \%$ of the respondents said that they received more than $10 \%$ of the data from digital devices.

In our identification of ERP implementation drivers in the region's agriculture we relied on technologies that had been adopted or were under development. The most likely fields for ERP implementation in agriculture were determined based on the findings obtained at the previous step of the study. The respondents were offered to give their own answer, if ERP implementation was not included in the available answers (Fig. 3). 


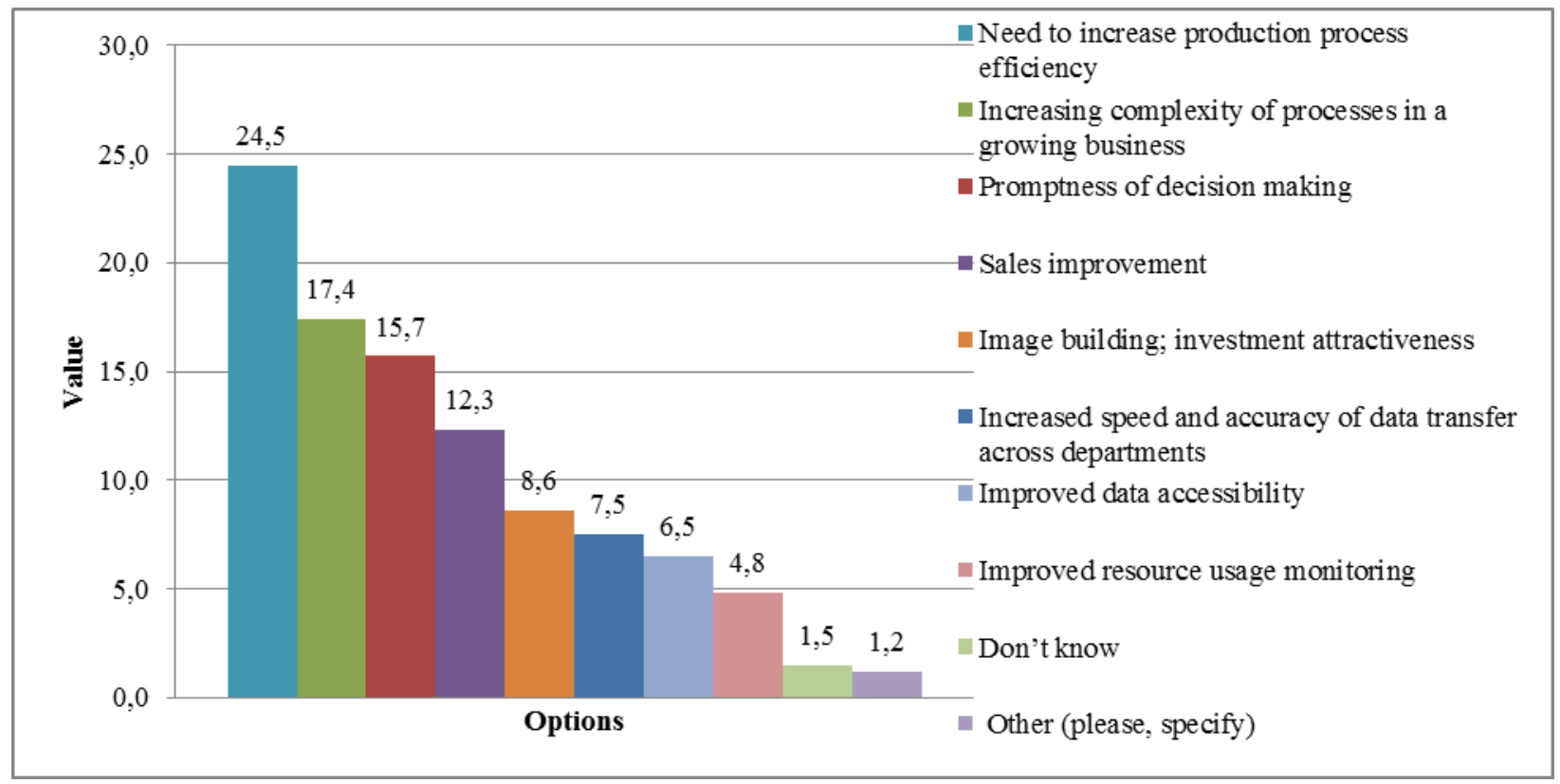

Fig. 3. Drivers of ERP implementation in agricultural companies - the respondents' opinion, Source: authors

Most of the respondents (24.5\%) agree that ERP implementation can increase production process efficiency. Substantial interest $(17.4 \%)$ is generated by ERP implementation necessitated by increasing complexity of processes in a growing business. Quite a few respondents $(12.3 \%)$ were interested in prospects for improving sales through better information exchange between the production and sales departments.

Unexpectedly, the need to increase speed and accuracy of data transfer across departments did not arise any particular interest among the respondents (7.5\%). Adoption of ERP systems can improve transparency of a company, thus boosting its investment attractiveness (8.6\%). The preferences of top managers and key employees of agricultural companies depend on organizational, economic, natural and other operation characteristics typical of the region; therefore, they need additional studies.

The ERP post-implementation benefits expected by the respondents - top managers and key employees of agricultural companies are shown in Fig. 4. 


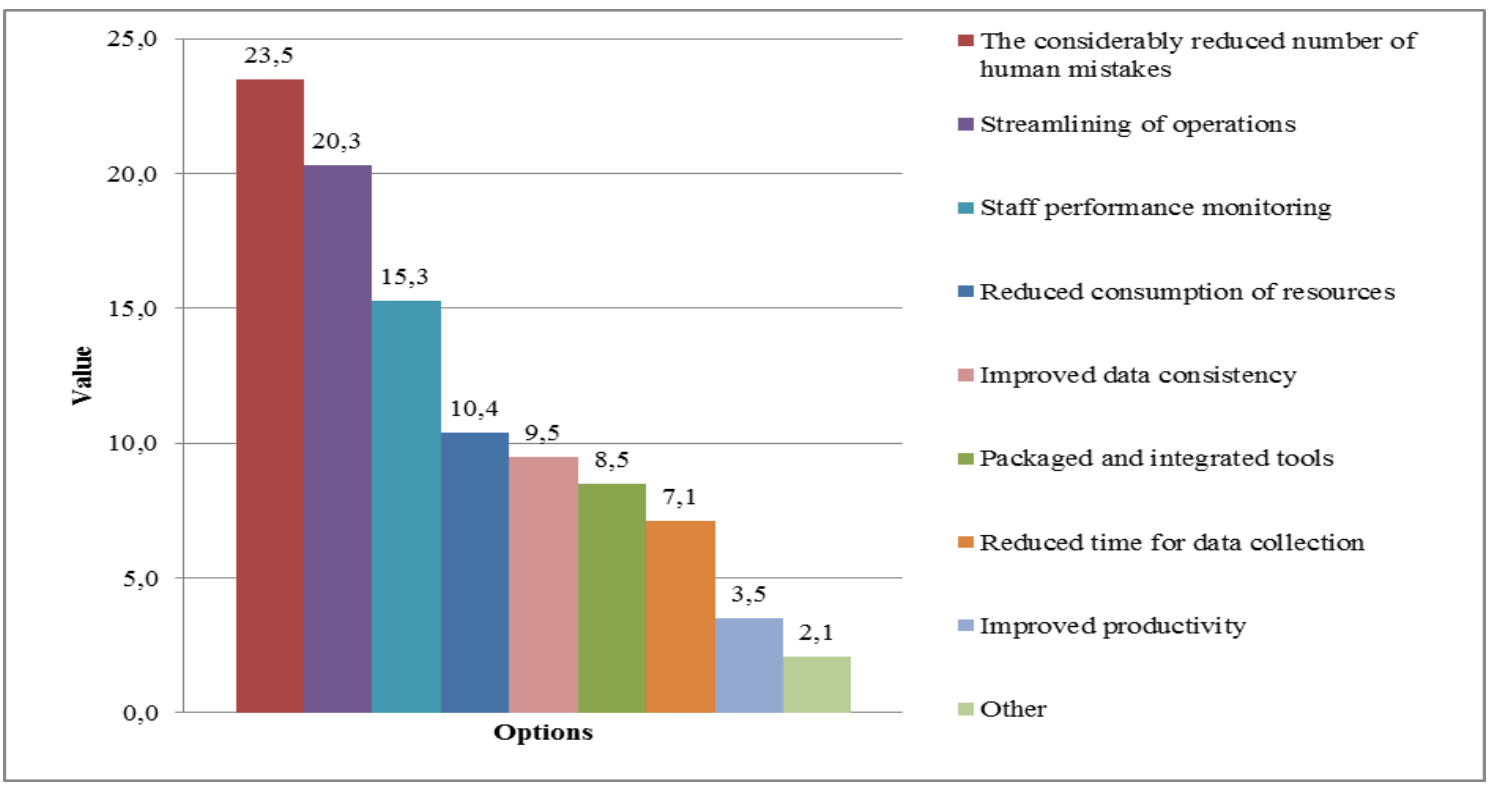

Fig. 4. Expected benefits of ERP implementation, Source: authors

The respondents expect that ERP implementation will help reduce human mistakes (23.5\%), optimize the processes $(20.3 \%)$, improve human resource management $(15.3 \%)$. The expectations are also connected with improved data exchange $(9.5 \%)$. Quite a few respondents $(15.3 \%)$ are interested in improved staff performance monitoring.

A significant number of respondents (39.4\%) pointed out that ERP systems would help increase revenue and profitability; $18.5 \%$ of the respondents expect that ERP systems will increase profitability by $5-9 \% ; 8.5 \%$ of the respondents believe that it will increase by over $20 \%$ (Fig. 5).

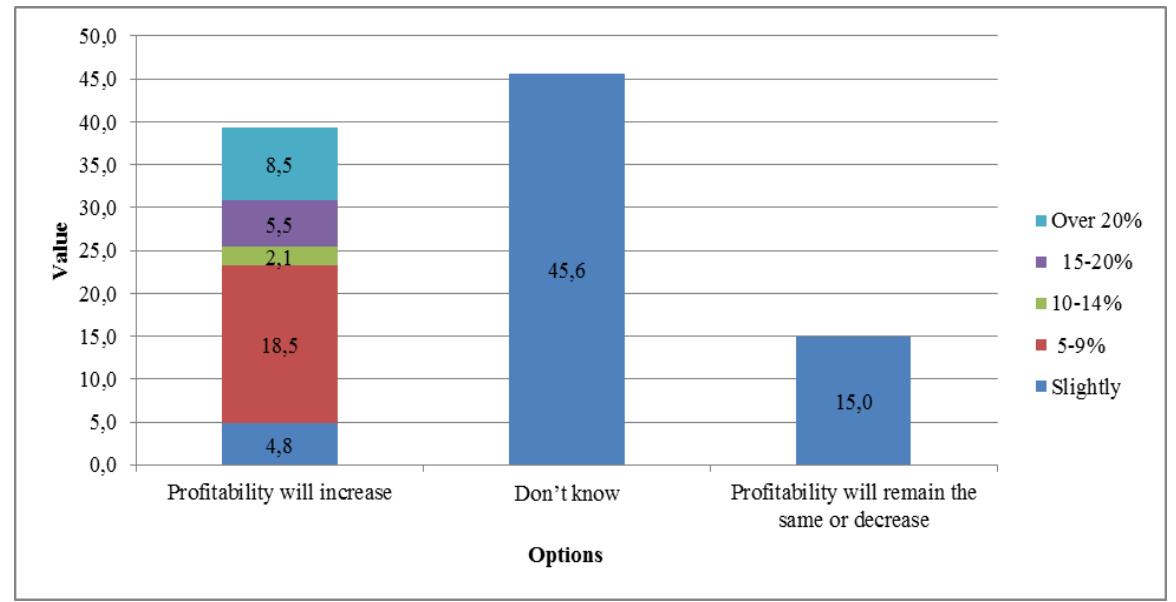

Fig. 5. Expected profitability increase resulted from ERP implementation in agriculture, Source: authors

In the meantime, the survey shows that quite a large number of respondents (15.0\%) are skeptical about ERP systems or find it difficult to answer the question (45.6\%). Apparently, it can be explained by the novelty of the ERP technology as well as by poor awareness of ERP implementation impact. 
Implementation of ERP systems in agriculture can encounter a number of barriers and natural constraints. In the opinion of top managers and key employees of agricultural companies, the main problems are lack of trained and skilled workers capable of operating ERP systems (26.5\% of the respondents) and lack of funds (23.6\%). Note that the implementation costs can range significantly - from several thousand rubles for a suite to hundreds and millions of rubles (Fig. 6).

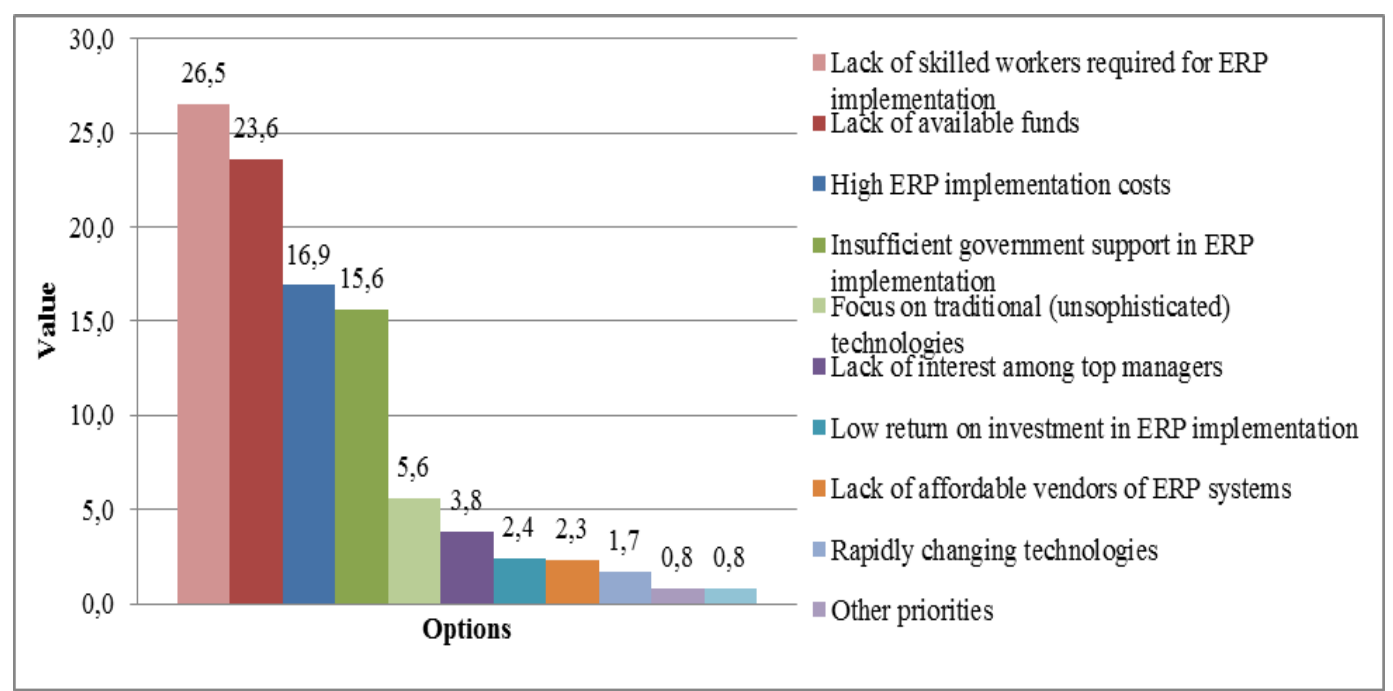

Fig. 6. Main barriers and challenges in implementation of artificial intelligence technology in agriculture, Source: authors

Quite a few respondents (16.9\%) pointed out high costs of ERP implementation and insufficient government support. The Russian government gives priority to subsidies aimed at development of dairy and beef farming, crop production, equipment and machinery procurement, etc. Complex innovative technologies, including ERP systems, are not subject to government support. Furthermore, a large number of ERP components and parts are available only from foreign manufacturers and vendors, which makes it difficult to reimburse implementation expenses.

ERP implementation in companies needs building a project team and engaging third-party contractors. However, insufficient skills and competencies of vendors, as pointed out by $2.3 \%$ of the respondents, impede significantly the above process. Control systems for agricultural businesses are intended to integrate most of the technologies into a single software and hardware system. The dominant place is still taken by accounting or packaged ERP solutions. Lately, there have been comprehensive solutions tailored to specific needs of the agriculture industry. For example, the ExactFarming Company came up with the solution for real-time field monitoring and agricultural production management. The ANT Company has designated projects in crop farming both for private and public entities. In the last 2-3 years, a number of agriculture-specific solutions have been offered by Borlas, a well-known integrator (systems for process monitoring, systems for crop planning, accounting and analytics portals for poultry farms, etc.).

Implementation of systems intended to automate management and operation of agricultural businesses encounters a number of problems in Russia. One of them is lack of business owners' confidence in high-tech solutions, which translates into insufficient support of projects from corporate management and makes projects difficult to implement. The departments' reluctance to share confidential information has an adverse impact on the efficiency of the system. Other adverse factors include insufficiently trained personnel, problems related to timely data entry and accuracy maintenance in ERP systems. 
By using the SWOT analysis we can assess the process of ERP implementation in agricultural companies. We should point out that ERP systems are difficult to fit into and get adapted to Russian conditions as well as to conditions of a specific company. Unlike off-the-shelf packaged software, ERP systems fall into the category of custom-built software requiring time-consuming adjustment and reprogramming of individual components to make them fit for further usage (Table1).

Table 1. SWOT - Analysis of ERP Implementation in Agriculture

\begin{tabular}{|c|c|}
\hline Strengths & Weaknesses \\
\hline $\begin{array}{l}\text { Improved performance and reduced costs due to ERP } \\
\text { implementation }\end{array}$ & Lack of available funds for ERP implementation \\
\hline Cost control & $\begin{array}{l}\text { Using outdated programs in training of employees in industry- } \\
\text { related educational institutions; insufficient competencies in ERP } \\
\text { implementation in the agriculture industry }\end{array}$ \\
\hline $\begin{array}{l}\text { Development of the resource planning system in } \\
\text { agricultural companies }\end{array}$ & $\begin{array}{c}\text { Poorly developed or absent infrastructure; difficulties in } \\
\text { adjustment and adaptation of ERP systems }\end{array}$ \\
\hline $\begin{array}{l}\text { Foundation for implementation of technologies used in } \\
\text { precision agriculture }\end{array}$ & Employees' and departments' reluctance to adopt ERP systems \\
\hline Opportunities & Threats \\
\hline Rapid development of digital technologies for agriculture & $\begin{array}{l}\text { Lack of confidence in high-tech solutions from agricultural } \\
\text { business owners }\end{array}$ \\
\hline $\begin{array}{l}\text { Integration with consumers of food products makes it } \\
\text { possible to monitor changes in consumer behavior }\end{array}$ & $\begin{array}{c}\text { Insufficient government support and funding in ERP } \\
\text { implementation }\end{array}$ \\
\hline $\begin{array}{l}\text { Development of programs for industry digitalization; } \\
\text { increased interest from the top management }\end{array}$ & $\begin{array}{l}\text { High prices for ERP systems; difficulties in measuring ERP } \\
\text { commercial performance }\end{array}$ \\
\hline Availability of ready-made ERP solutions for agriculture & Poor awareness of ERP systems among agricultural producers \\
\hline
\end{tabular}

On the other hand, while analyzing different ERP systems, we came across a number of open source business solutions where the ADempire, as we believe, takes the lead. The system was developed by the team consisting of more than 30 people and includes around 20 modules automating core business processes.

\section{Conclusions}

The study addresses prospects and challenges associated with ERP implementation; the priority attention is given to adoption and implementation of ERP systems in agricultural companies. We have attempted to identify key factors having an impact on the process of ERP implementation in the agriculture industry.

Top managers and key employees should set specific criteria to measure the ERP post-implementation efficiency so that the feasibility of these systems could be assessed. In our opinion, ERP systems will help improve accuracy of management decisions in agriculture and will lay the foundation for precision agriculture.

\section{References}

Davenport T. H., Brooks J. D. 2004. Enterprise systems and the supply chain, Journal of Enterprise Information Management, 17, pp. 8-19. https://doi.org/10.1108/09576050410510917

Ross J. W., Vitale M. R. 2000. The ERP Revolution: Surviving vs. Thriving, Information Systems Frontiers, 2 , pp. $233-241$. https://link.springer.com/article/10.1023\%2FA\%3A1026500224101

Haddara M., Elragal A. 2013. ERP Lifecycle: When to Retire Your ERP System? Information Management Journal (IRMJ), $26(1), 1-11$. https://doi.org/10.4018/irmj.2013010101 


\section{ENTREPRENEURSHIP AND SUSTAINABILITY ISSUES}

ISSN 2345-0282 (online) http://jssidoi.org/jesi/

2020 Volume 7 Number 3 (March)

http://doi.org/10.9770/jesi.2020.7.3(27)

Akkermans H. A., Van Helden K. 2002. Vicious and virtuous cycles in ERP implementation: a case study of interrelations between critical success factors. European Journal of Information Systems, 11, pp. 35-46. https://doi.org/10.1057/palgrave/ejis/3000418

Peng G. C. A., Gala C. 2014. Cloud ERP: a new dilemma to modern organisations? Journal of Computer Information Systems, 54(4), pp. 22-30. https://doi.org/10.1080/08874417.2014.11645719

Bento R., Bento A., Bento A. 2015. How fast are enterprise resource planning (ERP) systems moving to the cloud. Journal of Information Technology Management, 26(4), pp.35.

Abdrakhmanova G.I., Vishnevsky K.O., Gokhberg et al. 2019. Digital economy: a brief statistical compilation / Nat researched University "Higher School of Economics". - M : HSE, 2019 .-- 96 s https://www.tambov.gov.ru/site/it/files/doc/satatisticheskij-sbornik.pdf

Robey D., Ross J. W., Boudreau M.-C. 2002. Learning to Implement Enterprise Systems: An Exploratory Study of the Dialectics of Change, Journal of Management Information Systems, 19, pp. 17-46. https://doi.org/10.1080/07421222.2002.11045713

Costa C.J., Ferreira E., Bento F., Aparicio M. 2016. Enterprise resource planning adoption and satisfaction determinants. Computers in Human Behavior, 63, pp. 659-671. https://doi.org/10.1016/j.chb.2016.05.090

Klaus H., Rosemann M., Gable G.G. 2000. What is ERP? Information Systems Frontiers, 2, pp. 141. http://doi.org/https://doi.org/101023/

Vlasov, A.I., Grigoriev, P.V., Krivoshein, A.I, Shakhnov, V.A., Sergey S. Filin, S.S., Migalin, V.S. 2019. Smart management of technologies: predictive maintenance of industrial equipment using wireless sensor networks. Entrepreneurship and Sustainability Issues, 6(2), 489-502. http://doi.org/10.9770/jesi.2018.6.2(2)

Acar M. F., Tarim M., Zaim H., Zaim S., Delen D. 2017. Knowledge management and ERP: complementary or contradictory? International Journal of Information Management, 37(6), pp. 703-712. https://doi.org/10.1016/j.ijinfomgt.2017.05.007

1C: Enterprise 8. 2019. ERP Agriculture 2 Source: https://solutions.1c.ru/catalog/erpapk/features

BARS Agriculture. 2019. Source: https://bars.group/solution/regional-patterns/selskoe-khozyaystvo/

Navigator - Agro. 2019. Source: Navigator

Industry Solutions Company. 2019. Centerprogramsystem. Source: https://1cps.ru/solutions

Rostelecom Business Solutions. 2019. Source: $\underline{\text { https://ekt.rt.ru/b2b }}$

Wolfert S., Ge, L.; Verdouw C.; Bogaardt M.J. 2017. Big Data in Smart Farming - A review. Agricultural Systems. Vol.153 pp. 69-80 DOI: $10.1016 /$ j.agsy.2017.01.023

Rao B.B.P., Saluja P., Sharma N., Mittal A., Sharma S.V. 2012. Cloud computing for Internet of things \& sensing based applications // 2012 Sixth International Conference on Sensing Technology, pp. 374 - 380. doi:10.1109 / ICSensT.2012.6461705

Kaloxylos A., Eigenmann R., Teye F., Politopoulou Z., Wolfert S., Shrank C., Dillinger M., Lampropoulou I., Antoniou E., Pesonen L., Nicole H., Thomas F., Alonistioti N., Kormentzas G. 2012. Farm management systems and the Future Internet era // Computers and Electronics in Agriculture Vol. 89. P. 130 - 144. DOI: 10.1016/j.compag.2012.09.002.

Li L., Hu X., Chen K., He K. 2011. The applications of WiFi-based wireless sensor network in internet of things and smart grid. // 20116 th IEEE Conference on Industrial Electronics and Applications (ICIEA), pp. 789 - 793. doi: 10.1109 / ICIEA.2011.5975693

Mayeh, M., Ramayah, T., Mishr, A. 2016. The role of absorptive capacity, communication and trust in ERP adoption. Journal of Systems and Software, 119, pp. https://doi.org/10.1016/j.jss.2016.05.025

Nwankpa, J.K. 2015. ERP system usage and benefit: A model of antecedents and outcomes. Computers in Human Behavior, 45, pp. 18491864, https://doi.org/10.1016/j.chb.2014.12.019

Mahmud, I., Ramayah, T., Kurnia, S. 2017. To use or not to use: Modelling end user grumbling as user resistance in pre-implementation stage of enterprise resource planning system. Information Systems, vol. 69, pp. 164-179. https://doi.org/10.1016/j.is.2017.05. 005 


\title{
ENTREPRENEURSHIP AND SUSTAINABILITY ISSUES
}

ISSN 2345-0282 (online) http://jssidoi.org/jesi/

2020 Volume 7 Number 3 (March)

http://doi.org/10.9770/jesi.2020.7.3(27)

\section{Acknowledgements}

The reported study was funded by RFBR and Sverdlovsk region, project number 19-41-000001, Russian Federation

Ivan KULIKOV - Doctor of Economics, digital economy, smart garden, gardening, import substitution, convergent technologies, local monitoring, local garden

ORCID ID: 0000-0001-8071-0931

\begin{abstract}
Aleksandr SEMIN - Doctor of Economics, Professor Scientific interests: concentrated in the field of organizational and economic mechanisms for the reproduction of qualified agricultural personnel, as well as the technical potential of agricultural production; an effective mechanism for budget support of business entities in the agricultural sector; strategic planning and management.

ORCID ID: 0000-0001-8270-2257
\end{abstract}

Egor SKVORTSOV - PhD in Economics, research interests: development of the economic mechanism for applying digital technologies, agricultural robotics, development of the organizational and economic mechanism for sustainable land management based on modern digital technologies,

ORCID ID: 0000-0003-2034-951X

Natalia ZIABLITCKAIA - Doctor of Economics, Professor Scientific interests: business planning, competitive advantages of the organization, lean manufacturing, development of petrochemical clusters, petrochemical industry.

ORCID ID: 0000-0001-5768-1546

Ekaterina SKVORTSOVA - teacher, research interests: agricultural economics, robotics, digital technologies, agricultural labor, human capital.

ORCID ID: 0000-0001-9341-4453

Register for an ORCID ID:

https://orcid.org/register

Copyright (C) 2020 by author(s) and VsI Entrepreneurship and Sustainability Center

This work is licensed under the Creative Commons Attribution International License (CC BY).

http://creativecommons.org/licenses/by/4.0/

(c) (i) Open Access 